\title{
Heat recovery with low temperature spray drying for thermochemical hydrogen production
}

\author{
V. N. Daggupati, G. F. Naterer \& K. S. Gabriel \\ University of Ontario Institute of Technology, Oshawa, Ontario, Canada
}

\begin{abstract}
This paper examines the heat transfer and evaporative drying of molten salt droplets in a thermochemical copper-chlorine $(\mathrm{Cu}-\mathrm{Cl})$ cycle of hydrogen production. An aqueous $\mathrm{CuCl}_{2}$ stream exiting from an electrochemical cell is preheated to $150^{\circ} \mathrm{C}$, before entering the flash dryer to produce solid $\mathrm{CuCl}_{2}(\mathrm{~s})$. The device must add sufficient heat to remove water and recover solid $\mathrm{CuCl}_{2}$. New innovations of heat recovery aim to develop alternatives to reduce costs and improve efficiency of the evaporation process for $\mathrm{CuCl}_{2}$ particle production. This includes a new method to pressurize the liquid stream sufficiently to atomize droplets through a pressure-reducing nozzle in the spray system, thereby enhancing the device's performance. The liquid phase flashes due to a sudden pressure drop. Unlike other thermochemical cycles, the $\mathrm{Cu}-\mathrm{Cl}$ cycle can take unique advantage of low-grade waste heat for spray drying and vaporizing processes at low temperatures. The powder produced by spray drying is then injected in a fluidized reactor to eventually produce hydrogen. A common byproduct of manufacturing processes, incinerators, industrial furnaces, etc. heat - can become a valuable resource through its utility for hydrogen production with the $\mathrm{Cu}-\mathrm{Cl}$ cycle.
\end{abstract}

Keywords: heat recovery, hydrogen production, thermochemical $\mathrm{Cu}$-Cl cycle.

\section{Introduction}

Hydrogen is a promising clean energy carrier of the future, since its oxidation does not emit greenhouse gases that contribute to climate change. A UOIT-led initiative in collaboration with Atomic Energy of Canada Ltd. and other partners is developing a new route to hydrogen production based on advanced CANDU 
(CANada Deuterium Uranium) and SCWR (Super Critical Water Reactor) nuclear technologies. Thermochemical water decomposition driven by nuclear heat with a copper-chlorine $(\mathrm{Cu}-\mathrm{Cl})$ cycle splits water into hydrogen and oxygen through intermediate copper and chlorine compounds. These chemical reactions form a closed internal loop that re-cycles all chemicals on a continuous basis, without emitting any greenhouse gases externally to the atmosphere. Unlike other sustainable energy resources (such as solar or wind), nuclear heat used in this thermochemical cycle can enable consistently large-scale production of hydrogen. The $\mathrm{Cu}-\mathrm{Cl}$ cycle could be potentially coupled with nuclear reactors to achieve significantly higher efficiencies and lower costs of large-scale hydrogen production than any other conventional technology.

Hydrogen demand is expected to increase dramatically over the next decade. About 50 million tons/year of hydrogen are needed worldwide (currently about a $\$ 282$ billion market). The transition to a "hydrogen economy" in the transportation sector would require a lot more hydrogen. In Canada, Alberta's oil sands need over 770,000 tons/year of hydrogen, which is projected to grow to over 2.8 million tons/year in 2020. All major auto-makers are making significant investments in hydrogen vehicles.

Over 200 cycles have been identified previously to produce hydrogen by thermochemical water decomposition from various heat sources, including nuclear and solar energy [1]. Lewis and Taylor [2] reported that a survey of the open literature between 2000 and 2005 did not reveal any more cycles. Very few have progressed beyond theoretical calculations to working experimental demonstrations that establish scientific and practical feasibility of the thermochemical processes.

Much effort internationally is being focused on the sulfur-iodine (S-I) cycle of thermochemical hydrogen production. It is a leading example that has been scaled up to a pilot plant level, with active work conducted by the Sandia National Laboratory (USA), Japan Atomic Energy Agency (JAEA), CEA(France) and others [3, 4]. JAEA has demonstrated a pilot facility up to 30 litres/hr of hydrogen with the S-I cycle. JAEA aims to complete a large S-I plant to produce $60,000 \mathrm{~m}^{3} / \mathrm{hr}$ of hydrogen by 2020 . This would be sufficient for about 1 million fuel cell vehicles. Japan has a goal to have 5 million fuel cell vehicles on the road by 2020 [5]. Korea (KAERI Institute) is collaborating with China to produce hydrogen with their HTR-10 reactor. Sadhankar et al. [6] have examined the production of hydrogen with high-temperature nuclear reactors. This paper examines a promising low-temperature alternative called the copper-chlorine $(\mathrm{Cu}-\mathrm{Cl})$ cycle. This cycle offers a number of advantages over the S-I cycle, including lower operating temperatures, capability of utilizing low-grade waste heat from nuclear reactors and lower-cost materials. This article investigates the heat requirements of low-temperature steps within the $\mathrm{Cu}-\mathrm{Cl}$ cycle and presents recent UOIT-led developments to build an integrated lab-scale $\mathrm{Cu}-\mathrm{Cl}$ cycle, in conjunction with Atomic Energy of Canada Ltd. and other partners.

Within the $\mathrm{Cu}-\mathrm{Cl}$ cycle, an aqueous $\mathrm{CuCl}_{2}$ stream exiting from an electrochemical cell is preheated to $150^{\circ} \mathrm{C}$, before entering the flash dryer to produce solid $\mathrm{CuCl}_{2}(\mathrm{~s})$. This paper examines whether lower temperature drying 
can be accomplished, thereby enabling low-grade waste heat recovery from nuclear power plants for purposes of hydrogen production. Several past studies have shown that low-grade heat can be utilized for evaporative drying processes. Lin and Chen [7] used an experimental glass filament method to examine air drying at low temperatures, down to $70{ }^{\circ} \mathrm{C}$ with air velocities of $0.55 \mathrm{~m} / \mathrm{s}$ and an initial droplet diameter of $1.45 \mathrm{~mm}$. A reaction engineering model was used to predict results under conditions of high humidity. A wider range of air velocities between 0.45 and $1.0 \mathrm{~m} / \mathrm{s}$ was also examined experimentally by the authors [8]. Using a lab-scale spray dryer, Ambike et al. [9] studied an amorphous solid dispersion process with a lab-scale spray dryer, with applications to pharmaceutical research. It was shown that spray drying could be accomplished down to temperatures of $35^{\circ} \mathrm{C}$, with feed rates between $4-6 \mathrm{~mL} / \mathrm{min}$ and outlet air temperatures of $26{ }^{\circ} \mathrm{C}$. Crafton and Black [10] studied n-hexane droplet evaporation at $60{ }^{\circ} \mathrm{C}$ on heated horizontal surfaces. Another example of lowtemperature spray drying is Walton's study [11] of droplet evaporation with air temperatures down to $23{ }^{\circ} \mathrm{C}$. Farid [12] determined the drying time of a 200 micron droplet with $20-30 \%$ solid composition is about 6 seconds at an air temperature of $70{ }^{\circ} \mathrm{C}$. Lin and Gentry [13] studied the effects of air temperature and concentration on drying times of calcium acetate, sodium chloride, ammonium chloride and other inorganic solutions. These past studies provide a useful basis, from which low-temperature spray drying in the $\mathrm{Cu}-\mathrm{Cl}$ cycle will be examined in this paper.

\section{Overview of the thermochemical $\mathrm{Cu}-\mathrm{Cl}$ Cycle}

The $\mathrm{Cu}-\mathrm{Cl}$ thermochemical cycle uses a series of reactions to achieve the overall splitting of water into hydrogen and oxygen as follows:

$$
\mathrm{H}_{2} \mathrm{O}(l) \rightarrow \mathrm{H}_{2}(\mathrm{~g})+1 / 2 \mathrm{O}_{2}(g)
$$

The $\mathrm{Cu}-\mathrm{Cl}$ cycle splits water into hydrogen and oxygen through intermediate copper and chlorine compounds. These chemical reactions form a closed internal loop that re-cycles all chemicals on a continuous basis, without emitting any greenhouse gases externally to the atmosphere. Steps in the $\mathrm{Cu}-\mathrm{Cl}$ cycle with and a possible realization of the cycle are shown in fig. 1 and table 1 , respectively.

In Step 3 (flash dryer) of the $\mathrm{Cu}-\mathrm{Cl}$ cycle, an aqueous $\mathrm{CuCl}_{2}$ stream exiting from the electrochemical cell is preheated to $150^{\circ} \mathrm{C}$, before entering the flash dryer to produce solid $\mathrm{CuCl}_{2}$ (s), which is required for Step 4. The device must add sufficient heat to remove the water and recover solid $\mathrm{CuCl}_{2}$. New innovations of heat recovery aim to develop alternatives to reduce costs and improve efficiency of the evaporation process for $\mathrm{CuCl}_{2}$ particle production.

\section{Evaporative spray drying in the $\mathrm{Cu}-\mathrm{Cl}$ cycle}

The droplet evaporation and drying time depend on the droplet size, air velocity, air temperature, air humidity and operating pressure. Either an energy balance or mass balance method below can be used to estimate the drying time of droplets. 
For the former method (energy balance), only three variables are used, namely droplet size, air velocity and temperature, while the latter method (mass transfer) includes all of the five variables. In the analysis below, the following range of variables will be examined: Droplet size: 10-5000 $\mu \mathrm{m}$, inlet air humidity: $0.0025-0.015 \mathrm{~kg}$ water $/ \mathrm{kg}$ dry air, air temperature: $35-70^{\circ} \mathrm{C}$, air velocity: $0.5-4$ $\mathrm{m} / \mathrm{s}$, operating Pressure: $0.5-1$ atm.

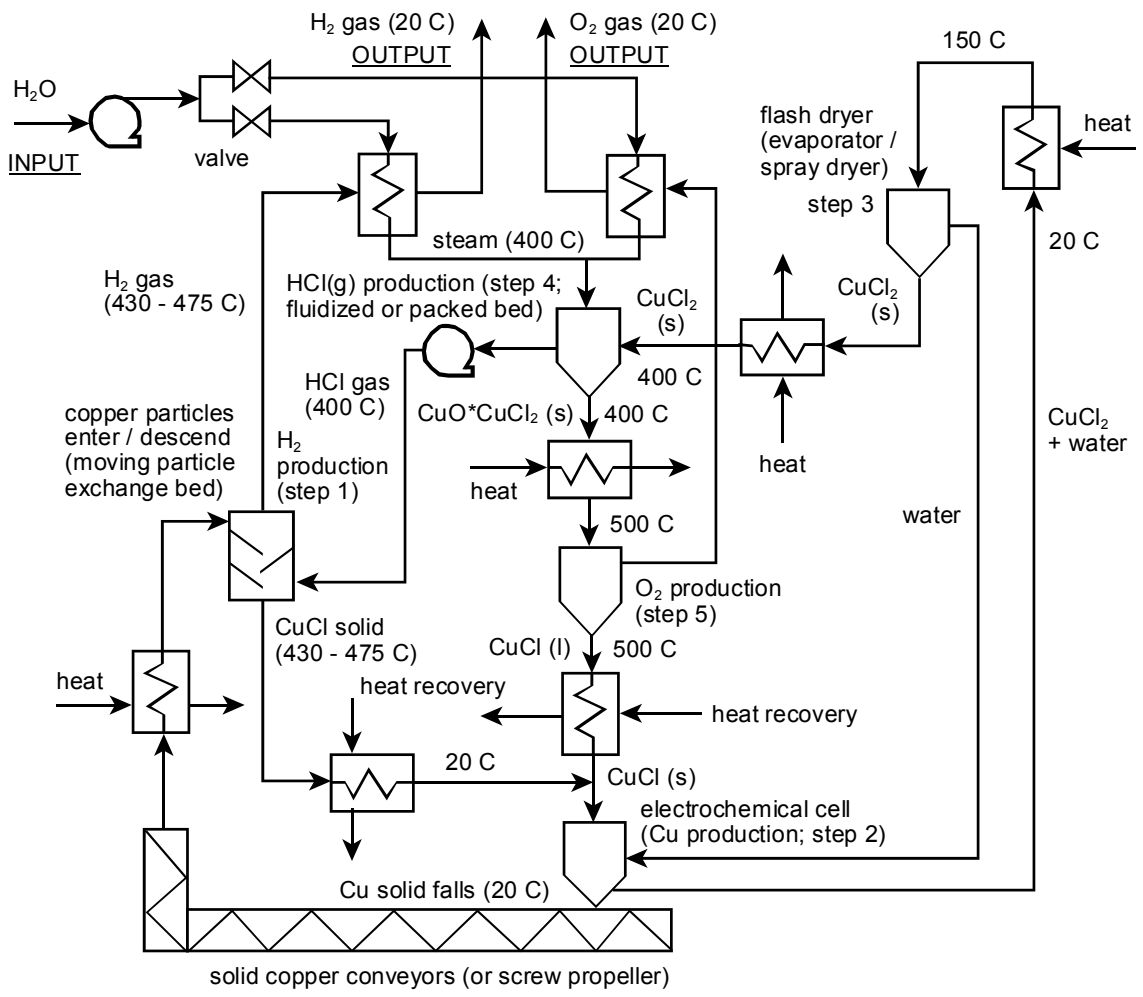

Figure 1: Conceptual layout of the $\mathrm{Cu}-\mathrm{Cl}$ cycle.

Table 1: Reaction steps in the $\mathrm{Cu}-\mathrm{Cl}$ thermochemical cycle for hydrogen production.

\begin{tabular}{|l|l|l|}
\hline Step & Reaction & \multicolumn{1}{|c|}{$\begin{array}{c}\text { Temperature } \\
\left({ }^{\circ} \mathbf{C}\right)\end{array}$} \\
\hline 1 & $2 \mathrm{Cu}(\mathrm{s})+2 \mathrm{HCl}(\mathrm{g}) \rightarrow 2 \mathrm{CuCl}(\mathrm{l})+\mathrm{H}_{2}(\mathrm{~g})$ & $430-475$ \\
\hline 2 & $2 \mathrm{CuCl}(\mathrm{s}) \rightarrow \mathrm{CuCl}_{2}(\mathrm{aq})+\mathrm{Cu}(\mathrm{s})$ & $\begin{array}{l}\text { Ambient } \\
(\text { electrolysis })\end{array}$ \\
\hline 3 & $\mathrm{CuCl}_{2}(\mathrm{aq}) \rightarrow \mathrm{CuCl}_{2}(\mathrm{~s})$ & $>100$ \\
\hline 4 & $\begin{array}{l}2 \mathrm{CuCl}_{2}(\mathrm{~s})+\mathrm{H}_{2} \mathrm{O}(\mathrm{g}) \rightarrow \\
\mathrm{CuO}^{*} \mathrm{CuCl}_{2}(\mathrm{~s})+2 \mathrm{HCl}(\mathrm{g})\end{array}$ & 400 \\
\hline 5 & $\mathrm{CuO}^{*} \mathrm{CuCl}_{2}(\mathrm{~s}) \rightarrow 2 \mathrm{CuCl}(\mathrm{l})+1 / 2 \mathrm{O}_{2}(\mathrm{~g})$ & 500 \\
\hline
\end{tabular}


The evaporation rate of a droplet $(\mathrm{kg}$ water / $\mathrm{s})$ is calculated from

$$
N_{c}=\frac{h_{c} A(\Delta T)}{\lambda}
$$

The drying time is then given by

$$
t=\frac{\pi d^{3} \rho_{w}}{6 N_{c}}
$$

The convective heat transfer coefficient can be determined from the following correlation for the Nusselt number

$$
N u=\frac{h_{c} d}{K_{d}}=2.0+0.6\left(\frac{d V \rho}{\mu}\right)^{0.5}\left(\frac{C_{p} \mu}{K_{d}}\right)^{0.33}
$$

The mass transfer rate ( $\mathrm{kg}$ water / s) from the droplet surface to the bulk air stream is calculated as follows,

$$
N_{c}=k_{c} A\left(C_{s}-C_{g}\right) M_{w}
$$

The mass transfer coefficient, $\mathrm{k}_{\mathrm{c}}$, can be estimated from the following correlation (6) and the drying time again is calculated using equation (3)

$$
S h=\frac{k_{c} d}{D_{g}}=2.0+0.6\left(\frac{d V \rho}{\mu}\right)^{0.5}\left(\frac{\mu}{\rho D_{g}}\right)^{0.33}
$$

From these correlations, and the following figures $2 \& 3$ and table 2 , it can be observed that the drying time rises with an increase in droplet size, inlet air humidity and operating pressure. The drying time decreases with an increase in air temperature and air velocity.

The spray drier volume depends on the air inlet temperature, outlet temperatures, solid concentration, feed flow rates, drying time, humidity and type of spraying. The effects of the above parameters are shown in figure 4 for a hydrogen capacity of $0.241-0.483 \mathrm{~kg} /$ day at the outlet air humidity of $90 \%$ saturation.

Table 2: $\quad$ Effect of droplet size on drying time at an air temperature of $35^{\circ} \mathrm{C}$, humidity of $0.015 \mathrm{~kg}$ water/ $\mathrm{kg}$ dry air, air velocity of $1 \mathrm{~m} / \mathrm{s}$ and drop temperature of $20^{\circ} \mathrm{C}$.

\begin{tabular}{|l|l|l|l|l|l|l|l|l|l|}
\hline $\begin{array}{l}\text { Droplet } \\
\text { size }\end{array}$ & $\begin{array}{l}10 \\
\mu \mathrm{m}\end{array}$ & $\begin{array}{l}50 \\
\mu \mathrm{m}\end{array}$ & $\begin{array}{l}100 \\
\mu \mathrm{m}\end{array}$ & $\begin{array}{l}300 \\
\mu \mathrm{m}\end{array}$ & $\begin{array}{l}400 \\
\mu \mathrm{m}\end{array}$ & $\begin{array}{l}500 \\
\mu \mathrm{m}\end{array}$ & $\begin{array}{l}1000 \\
\mu \mathrm{m}\end{array}$ & $\begin{array}{l}3000 \\
\mu \mathrm{m}\end{array}$ & $\begin{array}{l}5000 \\
\mu \mathrm{m}\end{array}$ \\
\hline $\begin{array}{l}\text { Drying } \\
\text { time, } \mathrm{s}\end{array}$ & 0.03 & 0.60 & 2.13 & 14.95 & 24.61 & 36.10 & 116.4 & 705.9 & 1601.1 \\
\hline
\end{tabular}


110 Advanced Computational Methods in Heat Transfer X

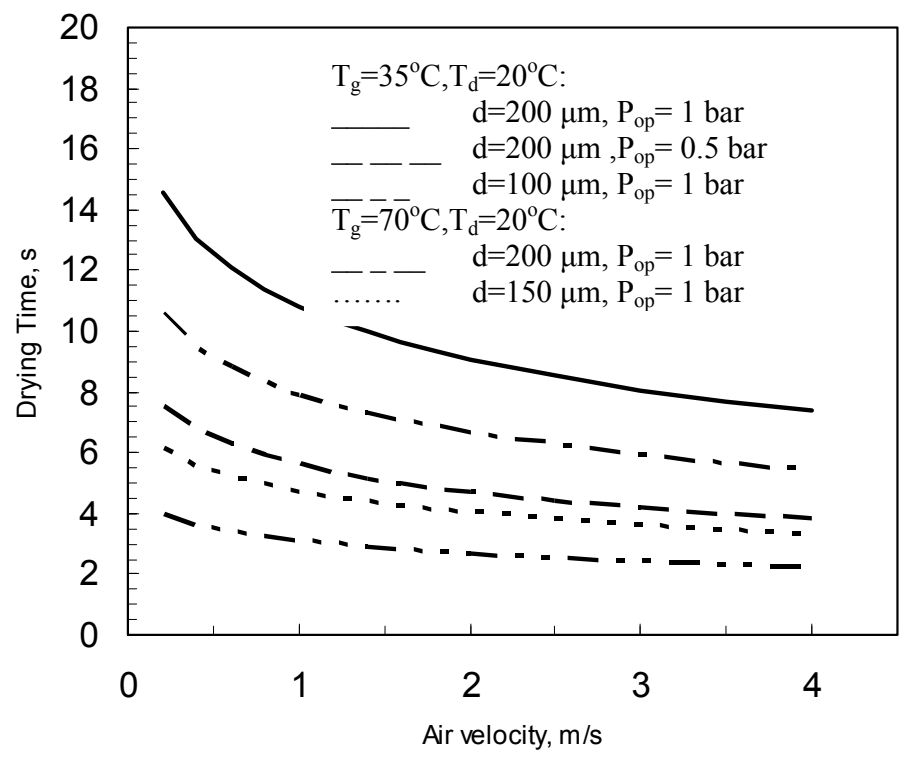

Figure 2: Variation of drying time with air velocity, temperature and operating pressure at an air humidity of $\mathrm{H}=0.01 \mathrm{~kg}$ water $/ \mathrm{kg}$ dry air.

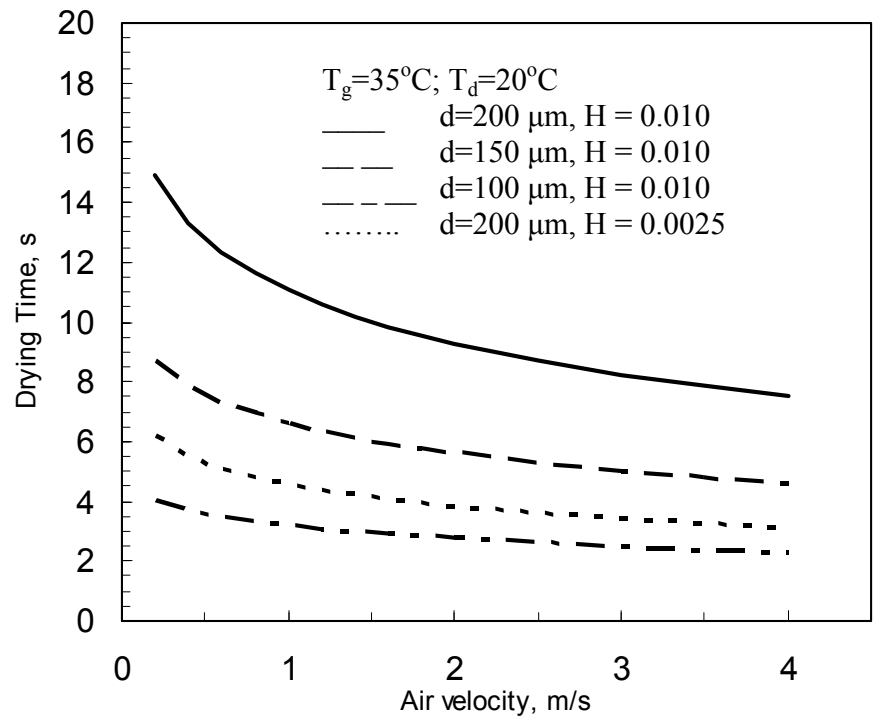

Figure 3: $\quad$ Variation of drying time with air velocity, humidity and drop size. 
In a spray drying operation, the selection of inlet and outlet air temperatures is very important. The temperature of the air flow does not need to be higher than the boiling point of water to evaporate the individual drops during the short residence times. The diffusive gradient between the wet surface and unsaturated air leads to evaporation at low temperatures. The optimal choice for the temperature difference between the inlet and the outlet temperatures is the melting point or decay temperature of the product, throughput and final moisture content of the product. The outlet temperature depends on the inlet temperature of air, mass flow rate of air, mass flow rate and solid concentration of the feed.

For small moisture content in the final product, the inlet temperature must be as high as possible and the temperature difference between inlet and outlet air must be as small as possible. Increasing the temperature difference between the inlet and outlet air, while holding the inlet air temperature constant, increases the moisture content in the final product. Figures 2 and 3 show the variation of drying time with air velocity. It was observed that the drying time strongly depends on the inlet air humidity. At a low humidity of $0.0025 \mathrm{~kg}$ water $/ \mathrm{kg}$ dry air, the drying time is less than $6 \mathrm{~s}$ for drop sizes less than $200 \mu \mathrm{m}$. At a humidity of $0.01 \mathrm{~kg}$ water $/ \mathrm{kg}$ dry air, the drying time is less than $6 \mathrm{~s}$ for drop sizes less than $100 \mu \mathrm{m}$, at $35^{\circ} \mathrm{C}$, and drop sizes less than $150 \mu \mathrm{m}$, at $70^{\circ} \mathrm{C}$. The analysis indicates that evaporative drying is possible down to low temperatures of $35^{\circ} \mathrm{C}$, although low temperature drying may limit the product quality and throughput.

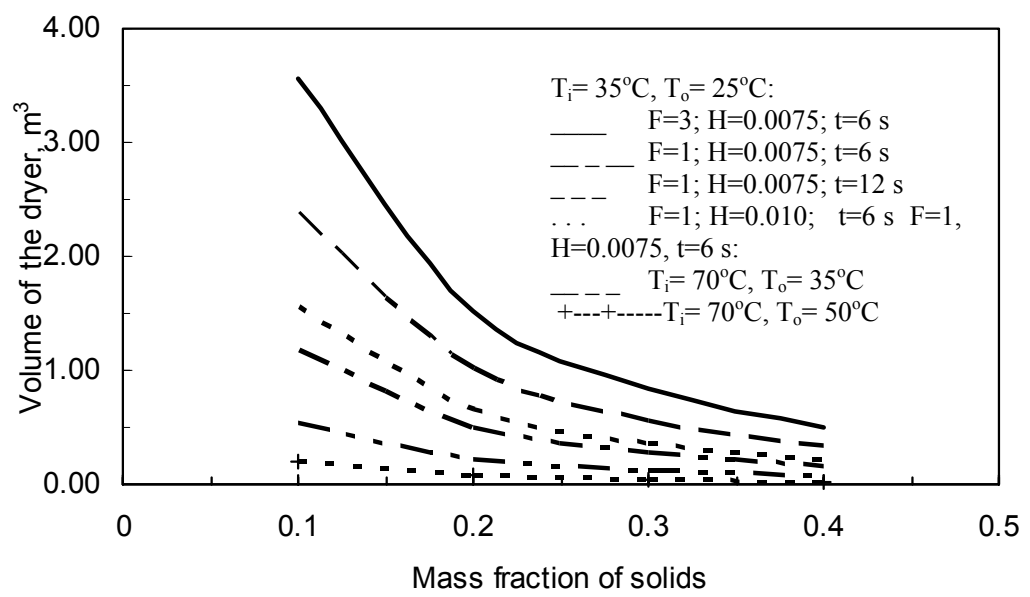

Figure 4: Variation of spray dryer volume with mass fraction of solids, feed flow rate, drying time, inlet air humidity, inlet and outlet air temperature.

For equipment selection in the spraying process of the $\mathrm{Cu}-\mathrm{Cl}$ cycle, the type of feed material is aqueous cupric chloride with $10-40 \%(\mathrm{w} / \mathrm{w})$ solid. Commonly used industrial equipment for such processes is a drum dryer or spray dryer. Both 
dryers can handle liquids and slurries. Also, both dryers have short residence times. Drum dryers produce flakes, while spray dryers produce porous, small rounded particles that are often preferable to flakes. Spray dryers are capable of large evaporation rates. Dust control is intrinsic to spray dryer construction, but not drum driers. A completely enclosed operation of spray dryers also is an advantage when toxic or noxious chemicals are handled.

The function of the spray dryer unit is to dry liquid $\mathrm{CuCl}_{2}$ solution into solid, by utilizing low-grade waste heat from nuclear or other sources. Spray drying involves evaporation of moisture from an atomized feed by mixing the spray and drying medium. The drying medium is typically air. The drying proceeds until the desired moisture content is reached in the sprayed particles and the product is then separated from air. The operating variables of the spray drier involve the atomizer design (type, rotational speed, nozzle diameter and number of nozzles), feed (flow rate, temperature and concentration) and air supply (flow rate, inlet temperature, outlet temperature and humidity). Scale-up of a commercial spray dryer requires optimization of the atomizer, feed, air conditions, and flow rates to determine the residence time. These factors are currently under investigation for construction of a cupric chloride spray dryer for a lab-scale demonstration of the $\mathrm{Cu}-\mathrm{Cl}$ cycle at UOIT.

\section{Conclusions}

In thermal power plants, many hundreds of megawatts of waste heat are typically transferred through condensers and moderator vessels to the environment (normally a nearby lake). This paper has examined low-temperature spray drying in a thermochemical cycle to reduce thermal pollution, particularly how waste heat can be diverted to cupric chloride drying for powder production in the $\mathrm{Cu}$ $\mathrm{Cl}$ cycle, rather than heat rejection to a lake. The powder product can then be transported to a fluidized reactor that eventually produces hydrogen. The $\mathrm{Cu}-\mathrm{Cl}$ cycle is a promising alternative to the sulfur-iodine cycle (S-I cycle; currently pursued by countries such as Japan, USA and France), due to its lower operating temperatures, lower cost materials and waste heat utilization from any nuclear or other industrial heat source(s).

\section{Acknowledgements}

Financial support of this research from Atomic Energy of Canada Ltd., Ontario Research Excellence Fund and the Natural Sciences and Research Council of Canada (NSERC) is gratefully acknowledged.

\section{Nomenclature}

A droplet surface area, $\mathrm{m}^{2}$

$\mathrm{C}_{\mathrm{p}} \quad$ specific heat, $\mathrm{J} / \mathrm{kgK}$

$\mathrm{C}_{\mathrm{s}} \quad$ vapor concentration at the droplet surface, $\mathrm{kmol} / \mathrm{m}^{3}$ 
$\mathrm{C}_{\mathrm{g}} \quad$ vapor concentration in the bulk air, $\mathrm{kmol} / \mathrm{m}^{3}$

$\mathrm{D}_{\mathrm{g}}$, diffusion coefficient for vapor in air, $\mathrm{m}^{2} / \mathrm{s}$

$\mathrm{F}$ feed flow rate, $\mathrm{kg} / \mathrm{hr}$

d droplet diameter, $\mathrm{m}$

$\mathrm{K}_{\mathrm{d}}$ thermal conductivity, $\mathrm{W} / \mathrm{mK}$

$\mathrm{k}_{\mathrm{c}} \quad$ mass transfer coefficient, $\mathrm{m} / \mathrm{s}$

$\mathrm{h}_{\mathrm{c}} \quad$ heat transfer coefficient, $\mathrm{W} / \mathrm{m}^{2} \mathrm{~K}$

$\mathrm{H}$ humidity of inlet air, $\mathrm{kg}$ water $/ \mathrm{kg}$ dry air

$\mathrm{M}_{\mathrm{w}} \quad$ Molecular weight of water, $18 \mathrm{~kg} / \mathrm{kmol}$

$\mathrm{P}_{\text {sat }} \quad$ vapor pressure of water at drop temperature, $\mathrm{N} / \mathrm{m}^{2}$

$\mathrm{P}_{\text {op }} \quad$ operating pressure, $\mathrm{N} / \mathrm{m}^{2}$

R gas constant, $8314 \mathrm{Nm} / \mathrm{kmolK}$

$\mathrm{t}$ drying time, $\mathrm{s}$

$\mathrm{T}_{\mathrm{d}} \quad$ droplet temperature, $\mathrm{K}$

$\mathrm{T}_{\mathrm{g}} \quad$ bulk air temperature, $\mathrm{K}$

$\mathrm{T}_{\mathrm{i}} \quad$ air inlet temperature, $\mathrm{K}$

$\mathrm{T}_{\mathrm{o}} \quad$ air outlet temperature, $\mathrm{K}$

$\mathrm{V}$ air velocity, $\mathrm{m} / \mathrm{s}$

$\mathrm{X}_{\mathrm{i}} \quad$ mole fraction of water vapor in air,

$\rho \quad$ density of air, $\mathrm{kg} / \mathrm{m}^{3}$

$\rho_{\mathrm{w}} \quad$ density of water, $\mathrm{kg} / \mathrm{m}^{3}$

$\mu \quad$ viscosity of air, $\mathrm{kg} / \mathrm{ms}$

$\lambda \quad$ latent heat of water, $2417.44 \mathrm{~kJ} / \mathrm{kg}$

$\Delta \mathrm{T}$ temperature difference between drying air and droplet

\section{References}

[1] McQuillan, B. W., Brown, L. C., Besenbruch, G. E., Tolman, R., Cramer, T., Russ, B. E., Vermillion, B. A., Earl, B., Hsieh, H. T., Chen, Y., Kwan, K., Diver, R., Siegal, N., Weimer, A., Perkins, C. \& Lewandowski, A, High efficiency generation of hydrogen fuels using solar thermochemical splitting of water: Annual Report, GA-A24972, General Atomics, San Diego, CA.

[2] Lewis, M. \& Taylor, A., High temperature thermochemical processes, DOE Hydrogen Program, Annual Progress Report, pp. 182-185, 2006, Washington, DC.

[3] Sakurai, M., Nakajima, H., Amir, R., Onuki, K. \& Shimizu, S., Experimental study on side-reaction occurrence condition in the iodinesulfur thermochemical hydrogen production process International Journal of Hydrogen Energy, 23, pp. 613-619, 2000.

[4] Schultz, K., Thermochemical production of hydrogen from solar and nuclear energy, Technical Report for the Stanford Global Climate and Energy Project, General Atomics, San Diego, CA, 2003.

[5] Fuel Cell Vehicles: Race to a new automotive future, US Department of Commerce, 2002. 
[6] Sadhankar, R. R., Li, J., Li, H., Ryland, D. \& Suppiah, S., Hydrogen generation using high-temperature nuclear reactors 55th Canadian Chemical Engineering Conference, October, Toronto, 2005.

[7] Lin, S. X. \& Chen, X. D., Prediction of air-drying of milk droplet under relatively high humidity using the reaction engineering approach, Drying Technology, 23, pp. 1395-1406, 2005.

[8] Lin, S. X. \& Chen, X. D., Air drying of milk droplet under constant and time dependent conditions, AIChE Journal, 51, pp.1790-1799, 2005.

[9] Ambike, A., Mahadik, K. R. \& Paradkar, A., Spray dried amorphous solid dispersions of simvastain a low Tg drug: in vitro and in Vivo evaluations, Pharmaceutical Research, 22, pp. 990-998, 2005.

[10] Crafton, E. F. \& Black, W. Z., Heat transfer and evaporation rates of small liquid droplets on heated horizontal surfaces, International Journal of Heat and Mass Transfer, 47, pp. 1187-1200, 2004.

[11] Walton, D. E., The evaporation of water droplets: a single droplet drying experiment, Drying Technology, 22, pp.431-456, 2004.

[12] Farid, M., A new approach to modelling of single droplet drying, Chemical Engineering, Science, 58 pp. 2985-2993, 2003.

[13] Lin, J. C. \& Gentry, J. W., Spray drying drop morphology: experimental study, Aerosol Science and Technology, 37, pp. 15-32, 2003. 